\title{
A qualitative study on social entrepreneurship: technology-based social ventures and humanitarian entrepreneurial mindset
}

\author{
Daniela STAICU \\ Bucharest University of Economic Studies, Bucharest, Romania \\ daniela.staicu@fabiz.ase.ro
}

\begin{abstract}
Seen as an effective approach for sustainable development of disenfranchised communities, spurring legislation initiatives and private investment, social entrepreneurship has gained the attention of many economies across the globe. Social entrepreneurship arises as an effective practice for solution development for access to education, healthcare, water, food, or electricity. In the United States, several university programs are tackling the development of technology-based social ventures. While there has been growth in assessing social entrepreneurship education, little exchange of what works in a technology-based social entrepreneurship program occurred.

To contribute to the body of empirical knowledge of what works in a program dedicated to technologybased solutions which have the potential to stimulate global improvements, the researcher performed a qualitative analysis of the Penn State HESE program's ENGR 451 course on social entrepreneurship. The purpose of this research was to gather some baseline data about three areas connected to developing culturally fit technology-based ventures and the humanitarian entrepreneurial mindset developed throughout this process. The paper reported on a grounded theory study using in-depth interviews with the 49 students enrolled in the ENGR 451 course on social entrepreneurship, 70\% studying engineering. The research analyzed two areas related to engineering entrepreneurship: the entrepreneurial mindset generated by participation in the course and the process of developing culturally fit technology-based social ventures with particular interest in task-role distribution, idea generation, and design-thinking stages. The current study is part of a larger qualitative study exploring how and what students in the HESE program learn about social entrepreneurship and how this learning influences their intent to be part of or to start a social venture.

The findings have potential impact across social entrepreneurship program design, are intended to inform educators of social entrepreneurs about social entrepreneurship program design and the humanitarian entrepreneurial mindset.
\end{abstract}

Keywords: design-thinking in social entrepreneurship, engineering entrepreneurship, entrepreneurial mindset, humanitarian mindset, social entrepreneurship, technology-based ventures.

\section{Introduction}

Over the last three decades, social entrepreneurship has gained the attention of many economies across the globe and policies were set in place to support the widespread of socially sustainable solutions. Seen as an effective approach for sustainable development of disenfranchised communities, spurring legislation initiatives and private investment (Rametse and Hetal, 2012; Osberg and Martin, 2015), social entrepreneurship become a practice for solutions development in areas related to access to education, healthcare, water, food or electricity (The World Bank, 2018; The United Nations, 2015). Moreover, the pressure exercised by the 2009 global economic crisis, has directed attention towards social entrepreneurs seen as agents of change (OECD/EU, 2017).

A gathering of unique businesses models, social entrepreneurship was first taught in business schools (Brock, 2011; Douglas, 2015). Recently it was associated with various disciplines 
in universities across the world. Engineering programs have connected social entrepreneurship to technology with the aim to prepare students to advance society through innovative technologies and a strong foundation of business knowledge. In the United States, more than ten universities are tacking the subject with the aim to transform engineers into global problem-solvers. Several academic journals focusing on humanitarian engineering and research related to the entrepreneurial mindset and to the venture development in the context of technology-based solutions have emerged. Typically, non-empirical descriptions of educational programs exceed empirical research (Huang-Saad et al., 2018). While there has been growth in assessing social entrepreneurship education, little exchange of what works in a technology-based social entrepreneurship program occurred.

To contribute to the body of empirical knowledge of what works in a program dedicated to technology-based solutions which have potential to stimulate global improvements, the researcher performed a qualitative analysis of the Penn State HESE program's ENGR 451 course on social entrepreneurship, on a cohort of 49 students. The purpose of this research was to gather some baseline data about three areas connected to developing culturally fit technology-based ventures and the humanitarian entrepreneurial mindset developed throughout this process.

In this paper, the research reports on a grounded theory study (Charmaz, 2006) using in-depth interviews with the students enrolled in the ENGR 451 course on social entrepreneurship, in a group of students where more than $70 \%$ are studying engineering. The current study is part of a larger qualitative study exploring how and what students in the HESE program learn about social entrepreneurship and how this learning influences their intent to be part of or to start a social venture. In this study, the researcher was mindful of existing theories and frameworks related to task-role distribution in work groups (Stempfle et al., 2001), idea generation in culturally fit social ventures (Zoltowski et al., 2012), and the entrepreneurial mindset of typical profit-oriented entrepreneurs (Gold and Rodriguez, 2018).

This article began with an overview of social entrepreneurship and the importance of its integration with humanitarian engineering before describing the content of the HESE Social Entrepreneurship course, ENGR 451. The methodology of this research is presented next. Third, the skills, attitudes, and behaviors towards social entrepreneurship that students develop throughout the course were analyzed. This was followed by an analysis of the ventures' development process with interest in task-role distribution, idea generation and design-thinking stages. This article culminated with a discussion about the entrepreneurial mindset and the ventures' development process research outcomes, and future work recommended for deepening the knowledge in the field.

The findings of this research have potential impact across design education and are intended to inform educators in social entrepreneurship about social entrepreneurship program design and the humanitarian entrepreneurial mindset generated through hybrid technology-based social entrepreneurship programs. The results of this study provide also rich information about the complex and variable process of learning in a real-life venture setting for the Penn State HESE community of professors, students, mentors, and researchers.

\section{Literature review}

The diffusion of social entrepreneurship business models has grown in many regions of the world, not only making visible progress in the United States and in Europe, but also attracting increasing interest in Eastern Asia and in Latin America (Defourny and Nyssens, 2010; Directorate-General for Employment, Social Affairs, and Inclusion, 2015; Japan Research Institute, 2016). Defined as 
the use of non-governmental, market-based approaches to address social issues, the social enterprise model can achieve both social and financial impact, addressing problems which stimulate legislation initiatives and to attract private investment (Bornstein and Davis, 2010; Rametse and Hetal, 2012; Osberg and Martin, 2015; Borgaza and Defourny, 2001).

According to the World Bank, over 1.9 billion people were living on less than $\$ 3.20$ per day in 2015, with no proper access to clean water and adequate sanitation, healthcare, education, or electricity with consequences for the family's well-being (The World Bank, 2018). International organizations are urging both developed and developing countries to support actions for ending poverty and other deprivations through solutions aimed to reduce inequality, all while paying attention to climate change (The United Nations, 2015). The pressure exercised by the 2009 global economic crisis which has resulted in widespread disgruntlement with the global economic system, called for more inclusive and diverse solutions (European Commission, 2014). This need has directed attention to the social enterprises' landscape, a gathering of unique businesses models.

Viewed as a model for poverty and social exclusion reduction (Parkinson, 2011; UNDP Regional Bureau for Europe and the Commonwealth of Independent States, 2008; OECD/EU, 2017), social entrepreneurship is being taught in universities across the world in diverse setups and connecting various disciplines (The Guardian, 2013).

Social entrepreneurship courses were first introduced in business schools two decades ago (Brock, 2011; Douglas, 2015), INSEAD Paris generating social entrepreneurship awareness and knowledge in Europe, and Harvard Business School in the United States (Smith-Milway and Driscoll-Goulay, 2013). More recently, particular attention has been paid to technology-based social entrepreneurship which aims transforming students into social problem-solvers and entrepreneurial global citizens. To reach this purpose, several academic programs have emerged: the Colorado School of Mines social entrepreneurship program (Arizona State University), the D-Lab (MIT), Design for Extreme Affordability (Stanford University), Development Engineering Program (University of California, Berkeley), the Engineering Service Learning for International Development (Villanova University), the Humanitarian Engineering and Science Minor (Missouri University of Science \& Technology), the Humanitarian Engineering and Social Entrepreneurship program (Penn State University), Humanitarian Engineering, Science and Technology (Oregon State University), the Mortenson Center in Engineering for Developing Communities (The University of Colorado, Boulder), and various international service projects, courses, and research in humanitarian engineering (The Ohio State University). Academic journals focusing on humanitarian engineering are contributing as well to the body of knowledge about social entrepreneurship: the International Journal for Service Learning in Engineering, the Journal of Humanitarian Engineering, and The Engineer and The Development of His Immediate Environment.

In this movement, from the traditional role to a modern one, where the engineer is leading actions oriented towards economically and socially sustainable development (Clough, 2005), the engineering educators are charged with the task of preparing students to advance development through innovative technologies and a strong foundation of knowledge. More and more, the universities are integrating knowledge and practice related to entrepreneurship, societal impact, entrepreneurial cultural opportunities and barriers, multidisciplinary teamwork and real-world field experience into educational programs, in a process of co-designing solutions with local-concerned stakeholders (The Guardian, 2018). Co-designing the solution is a key principle in the Penn State University Humanitarian Engineering and Social Entrepreneurship (HESE) program (HESE website, 2018). Non-empirical descriptions of educational programs exceed empirical research, 
and these empirical studies focus less on behavioral outcomes (Huang-Saad et al., 2018). Little emphasis is put on the process of assessing technology-based social ventures developed in an academic environment or on the humanitarian entrepreneurial mindset generated through these "hybrid" programs (table 1).

To provide an overview of research areas related to assessing engineering entrepreneurship academic programs, the researcher performed a literature review in the Web of Science and Scopus databases and sixteen papers were identified, among which five discussed the assessment of the entrepreneurial mindset and two presented an analysis of the venture development process.

Existing theories and frameworks related to task-role distribution in work groups (Stempfle et al., 2001), idea generation (Zoltowski et al., 2012), and entrepreneurial mindset characteristics of typical entrepreneurs (Gold and Rodriguez, 2018) were discussed.

Understanding the entrepreneurial mindset generated through educational courses has become a main vector for many programs, but efforts to describe it are scarce. The researcher connected our research on the Entrepreneurial Mindset Index developed by Gold and Rodriguez (2018) connected to the traditional entrepreneur who seeks above all profit. Their tool identified six knowledge domains: future orientation, opportunity recognition, communication and collaboration, critical thinking and problem solving, comfort with risk, and creativity. While performing the data analysis, any additional characteristics developed through the HESE ENGR 451 course were divided into new domains considered to belong to the HESE unique entrepreneurial mindset.

In terms of task-role distribution, the concept of task-role defined as one subtask or a set of subtasks assigned to each group member (Stempfle et al., 2001) was employed. The researcher has analyzed participants' actions in teams and compared teams' behaviors based on two principles: the principle of competence and the principle of preference. According to Stempfle et al. (2001), the principle of competence requires the group to structure itself around a group task, and to assign task roles to its members according to their individual skills. The principle of preference requires the group to consider individual preferences resulting from individual needs.

To understand the process of idea generation, the researcher analyzed the creative process of thinking: convergent and divergent thinking. Creative work includes both the convergent process of identifying relevant factual knowledge, and the divergent process of putting these together in new ways (Guilford, 1967; Runco, 2007; Weisberg, 1999). Convergent thinking refers to a mode that strives for the deductive generation of a single, concrete, accurate, and effective solution (Guilford, 1967), whereas divergent thinking, requires the generation of multiple disparate answers to a given problem, with imagination, unstructured syntheses, discovery outside the norm (Amabile, 1998).

The research related to understanding the process that inspires social entrepreneurs to adopt design thinking is scarce and little is known on how this process expands (Retna, 2016). For this purpose, the researcher analyzed how the process sequence of empathize - ideate - define prototype - test unfolds in the HESE ventures.

\section{Methodology}

\section{Rationale for choice of methodology}

Established in 1967 to reinstate inductive fieldwork by Glaser and Strauss, the grounded theory has evolved considerably since then and is now one of the most-used methodologies in qualitative research. A qualitative study allows the participants and researchers to discover new and unknown areas without the limitations of predetermined quantitative questions. A constructivist grounded 
theory methodology underpinned the study design, research questions, data collection, analysis, and interpretation. To achieve the scope of the study, the researchers developed a framework for applying the grounded theory (figure 1).

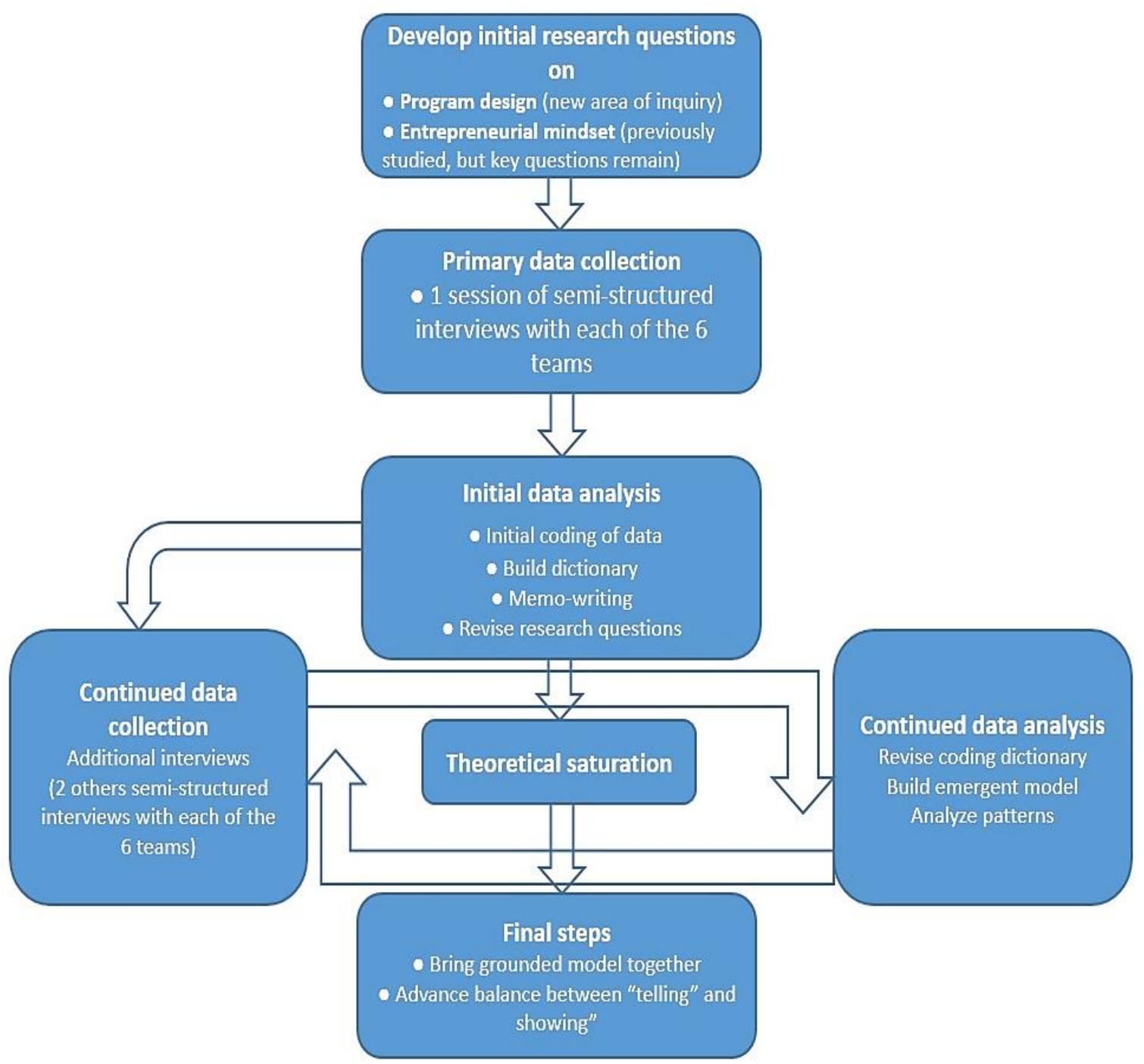

Figure 1. The grounded theory approach adapted to the study

Author's own processing.

The methods were also influenced by an informed grounded theory which recognizes pre-existing theories which can help the researcher to focus attention on certain phenomena, aspects, or nuances, providing a framework for thinking about a problem and for seeing beyond the data (Thornberg, 2012). In this study, the researcher was mindful of theories relating to taskrole distribution in work groups (Stempfle et al., 2001), idea generation (Zoltowski et al., 2012) and entrepreneurial mindset (Gold and Rodriguez, 2018).

The research questions were addressed during three stages of the data collection process set in the 7,10 and 14 weeks of the course (table 1). 
Table 1. Data collection stages and research questions

\begin{tabular}{|c|c|c|}
\hline $\begin{array}{l}\text { Data } \\
\text { collection } \\
\text { stages }\end{array}$ & $\begin{array}{l}\text { Group } \\
\text { semi-structured } \\
\text { interview }\end{array}$ & $\begin{array}{c}\text { Individual } \\
\text { paper based, semi-structured } \\
\text { interview }\end{array}$ \\
\hline \multirow{2}{*}{$1^{\text {st }}$ interview, week 7} & $\begin{array}{l}\text { How are the roles related to the } \\
\text { venture development process? }\end{array}$ & $\begin{array}{l}\text { What insights into entrepreneurship did you } \\
\text { get so far by working in a social venture? }\end{array}$ \\
\hline & $\begin{array}{l}\text { How is the venture development } \\
\text { process aligned to the design thinking } \\
\text { process? }\end{array}$ & $\begin{array}{l}\text { How do you feel about being part of a social } \\
\text { venture? }\end{array}$ \\
\hline \multirow{2}{*}{$\begin{array}{l}\text { 2nd interview, } \\
\text { Week } 10\end{array}$} & $\begin{array}{l}\text { How are the roles related to the } \\
\text { venture development process? }\end{array}$ & $\begin{array}{l}\text { What insights into entrepreneurship did you } \\
\text { get so far by working in a social venture? }\end{array}$ \\
\hline & $\begin{array}{l}\text { How is the venture development } \\
\text { process aligned to the design thinking } \\
\text { process? }\end{array}$ & $\begin{array}{l}\text { How do you feel about being part of a social } \\
\text { venture? }\end{array}$ \\
\hline $\begin{array}{l}\text { 3rd interview, } \\
\text { Week } 14\end{array}$ & $\begin{array}{l}\text { What are your recommendations for a } \\
\text { better venture development? }\end{array}$ & $\begin{array}{l}\text { How do you feel about starting a social } \\
\text { venture? }\end{array}$ \\
\hline
\end{tabular}

Author's own processing.

\section{Sample size}

In qualitative studies, the researcher had to be mindful about achieving data saturation, an element of the constant comparative method (Glaser and Strauss, 1996). The researcher determines the stage when the inclusion of more study subjects would add little to the understanding of the study phenomenon (Morse, 1995), and the researcher compares sequentially added events until saturation of properties of categories and of relations among them is reached (Charmaz, 2006). Saturation was achieved at the last stage of the ventures' design-thinking process, as it is laid out for this course prototyping. Three sessions of interviews with each of the six ventures scheduled in the 7,10 and 14 week of the course. The third and last data collection session was done when the teams achieved the last stage in design thinking: prototyping.

\section{Data collection}

The data was collected through semi-structured interviews (figure 2) scheduled over a period of three months and each team was interviewed three times. 


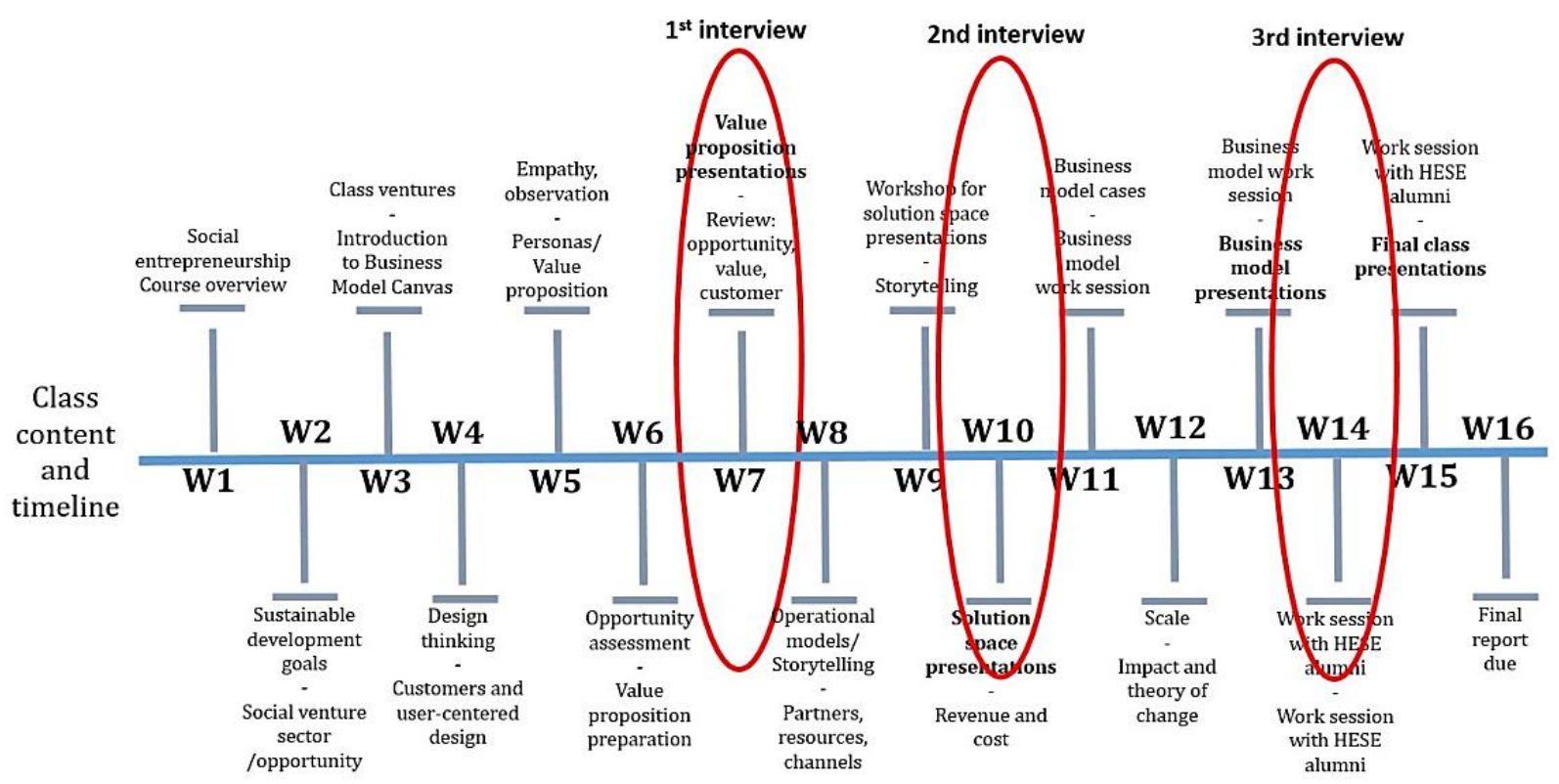

PICBE | 1102

Figure 2. Schedule of the interview sessions

Author's own processing.

Upon approval from the Institutional Review Board of Penn State University, the program director invited the students to join the research by signing a consent form. The participation was voluntary, and no remuneration was awarded (table 2).

Table 2. Data collection process

$\begin{array}{lcccc}\text { Timeline } & \begin{array}{c}\text { Research } \\ \text { Instrument }\end{array} & \text { Data collection } & \text { Form of data } & \text { Output }\end{array}$

\begin{tabular}{|c|c|c|c|c|}
\hline \multirow{2}{*}{$\begin{array}{l}\text { October 1st - } \\
\text { November } \\
\text { 30th } 2018\end{array}$} & \multirow{2}{*}{$\begin{array}{l}\text { Semi- } \\
\text { structured } \\
\text { Interview }\end{array}$} & \multirow{2}{*}{$\begin{array}{l}18 \text { interview sessions with } \\
\text { all } 49 \text { students enrolled in } \\
\text { the course, grouped in } \\
\text { their venture teams. } \\
\text { ( } 3 \text { interview sessions with } \\
\text { each of the } 6 \text { teams) }\end{array}$} & $\begin{array}{l}15 \text { hours of recorded } \\
\text { interviews followed by } \\
\text { transcribed interviews }\end{array}$ & $\begin{array}{l}\text { Data about the program } \\
\text { design (exploration of the } \\
\text { venture design). }\end{array}$ \\
\hline & & & $\begin{array}{l}\text { Individual structured } \\
\text { interviews } \\
\text { (paper-based) }\end{array}$ & $\begin{array}{l}\text { Data about students' } \\
\text { entrepreneurial mindset } \\
\text { (attitudes, skills and } \\
\text { behaviors related to social } \\
\text { entrepreneurship) }\end{array}$ \\
\hline
\end{tabular}

Author's own processing.

During the interviews, the participants came up with their own pseudonym to ensure that their privacy was protected. Participants were interviewed at a location of their choice on the campus, and each interview lasted 45 to 60 minutes, yielding a total of approximately 15 hours of recorded interviews. The interviews were audio taped and later transcribed and yielded approximately 42 pages of single-spaced text (table 2). We used open-ended questioning and determined the order of questioning by the direction taken by each interview participant. Interview data were held in password-protected files on password-protected computers. 


\section{Research on Entrepreneurial Mindset}

Throughout the first and the second interview, the participants were invited to share what insights into entrepreneurship they gained by being part of a venture, followed by questions related to feelings related to being part of a social venture. In the third interview, the research looked to understand which students have the intention to start a social venture.

The data collected through individual, semi-structured, paper-based interviews was divided into an existing theory about entrepreneurial mindset (table 3) developed by Gold and Rodriguez (2018). If the data collected could not be allocated to one of the six categories, a new category was defined, coded and new data collection and analysis was performed.

Table 3. The Entrepreneurial Mindset Index (Gold and Rodriguez, 2018)

EMI domains

Definition

\begin{tabular}{ll}
\hline \multicolumn{1}{c}{ EMI domains } & \multicolumn{1}{c}{ Definition } \\
\hline Opportunity recognition & $\begin{array}{l}\text { The practice of seeing and experiencing problems } \\
\text { as opportunities to create solutions. }\end{array}$ \\
Comfort with risk & $\begin{array}{l}\text { The capacity to move forward with a decision despite inevitable } \\
\text { uncertainty and challenges. }\end{array}$ \\
Creativity \& innovation & $\begin{array}{l}\text { The ability to think of ideas and create solutions to problems without } \\
\text { clearly defined structures. }\end{array}$ \\
Future orientation & $\begin{array}{l}\text { An optimistic disposition with a focus on obtaining the skills and } \\
\text { knowledge required to transition into a career. }\end{array}$ \\
Critical thinking \& & $\begin{array}{l}\text { The process of aplying higher-level, process-oriented, thinking skills and of } \\
\text { transitioning that applied reasoning to support decision making. }\end{array}$ \\
Problem solving & The ability to clearly express ideas to an intended audience, including \\
pommunication and collaboration
\end{tabular}

Source: Gold and Rodriguez (2018).

The data collected through group semi-structured interviews was divided into three areas of interest and analyzed. In the first two interviews, the research dived into how the team ventures are developing in terms of:

(1) Task-role distribution in the venture.

(2) Idea generation through convergent or divergent thinking.

(3) Unfolding of design-thinking stages in the venture development.

In the third interview, we invited the groups to reflect on how to improve the program design.

\section{Results and discussions}

The accuracy of the transcriptions was confirmed by comparing them with the audio-taped recordings. In terms of individual paper-based interviews, all data were introduced into the computer in separate files for each student identified through a pseudonym they kept throughout the research. The first stage of the analysis involved reading the transcript multiple times to acquaint with the data as well as to identify initial ideas as guidance for coding to note the emergent themes.

The data analysis was an ongoing process, taking place concurrently with the data collection (Patton, 2002). To develop the coding scheme, a thematic analysis defined as "a method for identifying, analyzing, and reporting patterns (themes) within data" (Braun and Clarke, 2006) was conducted. The researcher coded the initial data gathered in the first session after interviewing all 
six of the teams and conducted a line-by-line coding of the transcripts for both group and individual interviews. Open coding is the initial and unrestricted coding of data because this allows the researcher to freely consider meanings of words, phrases, and sentences (Lindlof and Taylor, 2002; Strauss and Corbin, 1998).

\section{Findings related to the Entrepreneurial Mindset}

In terms of entrepreneurial mindset, the data collected yielded nine categories of characteristics,

six belonging to the typical entrepreneurial mindset (table 4) as it is defined in the Entrepreneurial Mindset Index (Gold and Rodriguez, 2018) and three new categories (table 5).

\section{Table 4. Analysis of the HESE Entrepreneurial Mindset}

\section{Goal and Rodriguez (2018) \\ Entrepreneurial Mindset}

\section{Students' Quotes}

I learned much about the dynamics of introducing a new product to the bottom of the pyramid.

I learned how to develop a business plan.

Opportunity recognition

I discovered how many different components go into starting a venture.

I have gained a lot of business skills: creating a business model canvas and understanding networks, users, partners, pricing models, channels, and the importance of developing an Minimum Viable Product.

I understood that the customers are not aware that their life can be made easier.

Though in the beginning, but can be done with effort.

Comfort with risk I feel intimidated: launching a successful venture could be very difficult.

I am nervous and unsure about success.

Creativity \& innovation It is important to get work done, even if it is not exactly the right direction.

I think I have become more invested in the social venture since the start and am a little

Future orientation more invested in product, as a result.

I am now I am prepared to spend the beginning of my post-grad life in Africa starting my venture.

I learned how to think how to best help whereas before I would just jump straight to solution.

I have learned that it can be hard to see the progress or the big picture while in the

Critical thinking \& process, so you need outsiders to see the obvious things you cannot see.

Problem solving

Every detail matters and should be thouroughly though out.

I have learned how to properly conduct research, how to present and how to contact people who have the information I need.

I enhanced my presentation skills.

Communication and I learned how to tell a story and annunciate between data reasoning and conclusion.

collaboration I learned a lot about team management.

It is hard to have more than one leader.

Source: Author's own processing.

The three new categories included statements which did not belong in any of the six categories of a typical entrepreneurial mindset. These new categories were analyzed further in the second and third interview sessions and coded into three categories: focus on social impact, 
envisioning a social entrepreneurship career path, and mindful of culturally appropriate venturing. In this research, these categories were entitled: HESE-particular skills, attitudes, and behaviors (table 5).

Table 5. HESE skills, attitudes, and behaviors

\begin{tabular}{cc} 
HESE \\
$\begin{array}{c}\text { Skills, attitudes, } \\
\text { and behaviors }\end{array}$ & Students' Statements \\
\hline
\end{tabular}

It is very exciting having the potential to make a difference in the world.

Focus on Social Impact

I learned how challenging a social business is, and also how few students from US can make tangible differences.

I like the idea of doing something that could provide sustainable help.

It is a lot harder than I thought to create a sustainable social venture.

It is what I hope to continue doing throughout my life, creating my own.

I wish to become more involved as the venture moves forward.

Envisioning a Social Entrepreneurship Career Path
Not now, I don't think I have the expertise yet.

It is scary and a lot of work, but I think it will pay off in the end. Hopefully make a lasting impact on people who need it.

I myself I could never start a venture, but I enjoy working on one.

I am so excited to be starting a venture. I hope to work for the company in the future.

Establish contacts to get the information needed could be difficult.

Mindful of Culturally Appropriate Venturing
I learned that there are different cultural requirements for our social venture.

I never thought we must find local materials (in Kenya) and that they have to be cheap.

Author's own processing.

The nine categories resulted composed an outcome space with two distinct, but independent axes related to the typical entrepreneurial mindset, on one hand, and the HESE entrepreneurial mindset on the other hand, together forming the HESE Humanitarian Entrepreneurial mindset (table 6).

Table 6. HESE Humanitarian Entrepreneurial Mindset

\begin{tabular}{ll}
\hline & $\begin{array}{l}\text { Opportunity recognition } \\
\text { Comfort with risk } \\
\text { Creativity \& innovation } \\
\text { Future orientation } \\
\text { Traditional Entrepreneurial } \\
\text { Mindset }\end{array}$ \\
$\begin{array}{l}\text { Critical thinking \& Problem solving } \\
\text { Communication and collaboration }\end{array}$ \\
$\begin{array}{l}\text { FESE Entrepreneurial } \\
\text { Mindset add-ons }\end{array}$ & $\begin{array}{l}\text { Envisioning a Social Entrepreneurship Career Path } \\
\text { Mindful of Culturally Appropriate Venturing }\end{array}$ \\
\hline
\end{tabular}




\section{Culturally fit social enterprise design}

In terms of venture development, first was analyzed how task-roles are assigned in a team and the stages in design-thinking achieved, initially by week 7 (table 7 ).

Table 7. Participants' statements related to task-roles assigning up to week 7

\begin{tabular}{|c|c|c|}
\hline $\begin{array}{l}\text { Items / } \\
\text { Team no. }\end{array}$ & Task role assigning & Design-thinking stages \\
\hline $\mathbf{T 1}$ & $\begin{array}{l}\text { "We assigned everyone to research } \\
\text { one aspect each. We asked } \\
\text { volunteers for each topic." }\end{array}$ & $\begin{array}{l}\text { "Most of the progress has been made in terms of: getting } \\
\text { people on the same page; finding out what we need to do; } \\
\text { developing a plan." } \\
\text { "We are now more focused on the opportunity". } \\
\text { "We have a better understanding of our business model." }\end{array}$ \\
\hline $\mathbf{T 2}$ & $\begin{array}{l}\text { "We divided ourselves up into } 3 \\
\text { task groups. We don't really have } \\
\text { defined roles." }\end{array}$ & $\begin{array}{l}\text { "The project has pivoted on its business model since the } \\
\text { beginning of the year from "a razorblade" business model to } \\
\text { a "pay-as-you grow " good service." }\end{array}$ \\
\hline T3 & $\begin{array}{l}\text { "We identified } 3 \text { main topics and } 3 \\
\text { groups were created. The tasks } \\
\text { were assigned according to major. } \\
\text { These are not permanent groups; } \\
\text { we might be switching in the } \\
\text { future." }\end{array}$ & $\begin{array}{l}\text { "We gained clarity and understanding on our user, customer } \\
\text { and we did research on the e-commerce market, our } \\
\text { competitors and our network of designers." }\end{array}$ \\
\hline T4 & $\begin{array}{l}\text { "Loose roles. } \\
\text { As to who is doing what research, } \\
\text { we spent the first two weeks } \\
\text { familiarizing with the information, } \\
\text { and not necessarily assigning roles. } \\
\text { We definitely need to define roles } \\
\text { better." }\end{array}$ & "We changed our customer profile." \\
\hline T5 & $\begin{array}{l}\text { "We split roles based on people's } \\
\text { interest. Teams of } 2-3 \text { depends on } \\
\text { the work." }\end{array}$ & $\begin{array}{l}\text { "We are creating connections in Kenya - building } \\
\text { relationships: users and. We had to take a new perspective." }\end{array}$ \\
\hline T6 & $\begin{array}{l}\text { "We assigned roles according to } \\
\text { where people have more knowledge } \\
\text { but also helping out where needed. } \\
\text { A lot of research roles." }\end{array}$ & $\begin{array}{l}\text { "We took different routes to explore. } \\
\text { We explored what other value we can offer to our users and } \\
\text { customers beyond just a platform. } \\
\text { We developed personas for the first presentation. } \\
\text { We put fact behind our ideas - concrete numbers." }\end{array}$ \\
\hline
\end{tabular}

After dividing the data into two categories: task-roles and actions related to idea generation, the statements were coded into the following categories:

(1) Task-Role assigning

Code R1: Students solve tasks in groups of 3-4 students.

Code R2: Students work on tasks individually.

Code P: task-role is assigned based on the principle of preference.

Code $\mathrm{C}$ : task-role is assigned based on the principle of competence.

(2) Actions related to idea generation.

Code A1: Students explore one route.

Code A2: Students explore multiples routes;

(3) Stages in design-thinking

Codes: Empathize (E), Define (D), Ideate (I), Prototype (P), Test (T); 
After coding the data, the data was tabulated for fluent processing. These codes were kept throughout all three of the interview sessions.

The matrix reveals in terms of:

(1) Task-role: Are equally assigned by grouping students in teams of 3-4 students or individually, based either on preference or competency. There is no clear mechanism of assigning roles and it depends on how the leaders establish role assigning.

(2) Idea generation: Most of the teams' ideas are following one direction to explore and are characterized by convergent thinking (Guilford, 1967).

(3) Stages in design-thinking: In the first 7 weeks of the venture development, the students accomplish the first two stages of the design thinking process: empathize and define.

The analysis was continued using the codes defined previously in week 7 (table 8).

Table 8. Participants' statements related to tasks roles assigning up to week 10

\begin{tabular}{lll}
\hline Items / & Task roles assigning & Design-thinking stages \\
Team no. &
\end{tabular}

T1 "We made a division into groups, "We are focusing on the product development." and roles assigned on skills." "We made a few new compacts."

"We divided ourselves up into task groups. We defined roles after the 1st presentation."

"We gained more contacts and resources we can use to push our product further."

"Too many cooks in the kitchen at first.

"We are now trying to work towards a final product, "Splitting in smaller groups is towards results more than just research." effective."

"We are in the process where people are branching out. People took more responsibilities."

"There has been a change on who our current customers are going to be. Our end users are exactly the same but our way to getting to them has changed."

T5

"Our leader assigns tasks and "Just connecting with the customers we learned what they people choose what they want to learning about the people there. do from that list."

We are working on three fronts: 3 fronts: customer development, product development, Business Model. These we followed since the beginning".

"It took us a lot to split in groups, "We have started to prototype an app.Continuous

T6 4 groups. We assigned roles based on student's interest." research. There has been changes to the business model too."

Author's own processing.

After collecting the data in week 10, the researcher coded it into a matrix, following the same process as in week 7 (table 9).

Table 9. Coding matrix of task-role, idea generation, and stages in design thinking in week 10

DOI: $10.2478 /$ picbe-2021-0103, pp. 1096-1112, ISSN 2558-9652 |

Proceedings of the $15^{\text {th }}$ International Conference on Business Excellence 2021 


\begin{tabular}{cccc}
\hline $\begin{array}{c}\text { Items / } \\
\text { Team no. }\end{array}$ & $\begin{array}{c}\text { Task Role } \\
\text { assigning }\end{array}$ & $\begin{array}{c}\text { Idea } \\
\text { Generation }\end{array}$ & $\begin{array}{c}\text { Stages in design } \\
\text { thinking }\end{array}$ \\
\hline T1 & R1, C & A1 & I - P \\
T2 & R1, C & A1 & P \\
T3 & R1, C & A1 & I - P \\
T4 & R1, P & A1 & E - D - I \\
T5 & R2, C & A2 & D - I \\
T6 & R1, P & A1 & D - I - P \\
\hline
\end{tabular}

The matrix in week 7 and in week 10 in terms of:

(1) Task-role (figure 4).

Three of the six teams, the more advanced ventures, assigned task-roles based on competence, and students were divided into groups. Two of the six teams used this group-competence approach since the beginning of the venture.

Two of the six teams assigned the tasks based on preference in the beginning.

Three of the six teams kept the same approach of role-task division and individual or group assignment throughout the venture development.

Five of the six teams assigned the task-role in groups. Only one team kept their preference for assigning tasks to individuals, not to groups.

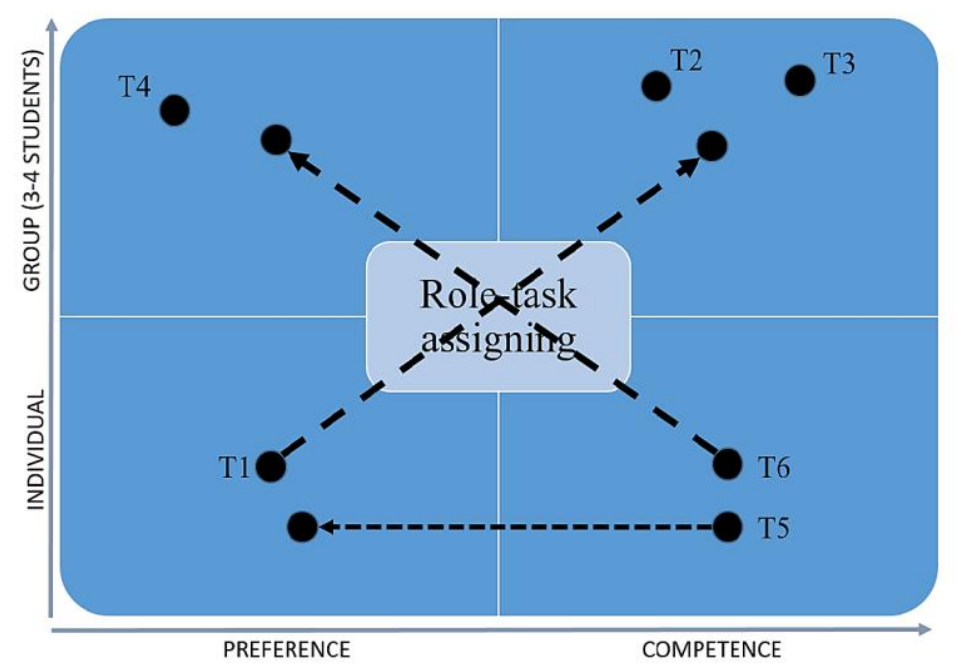

Figure 3. Role-task assigning process in week 7 and in week 10

(2) Actions

Authors' own processing.

Most of the teams' actions are directed towards one solution generated in one direction (convergent thinking).

(3) Stages in design-thinking

In the first ten weeks of the venture development, three of the six teams revised their business model and four of the six were in the prototyping phase (figure 4). 


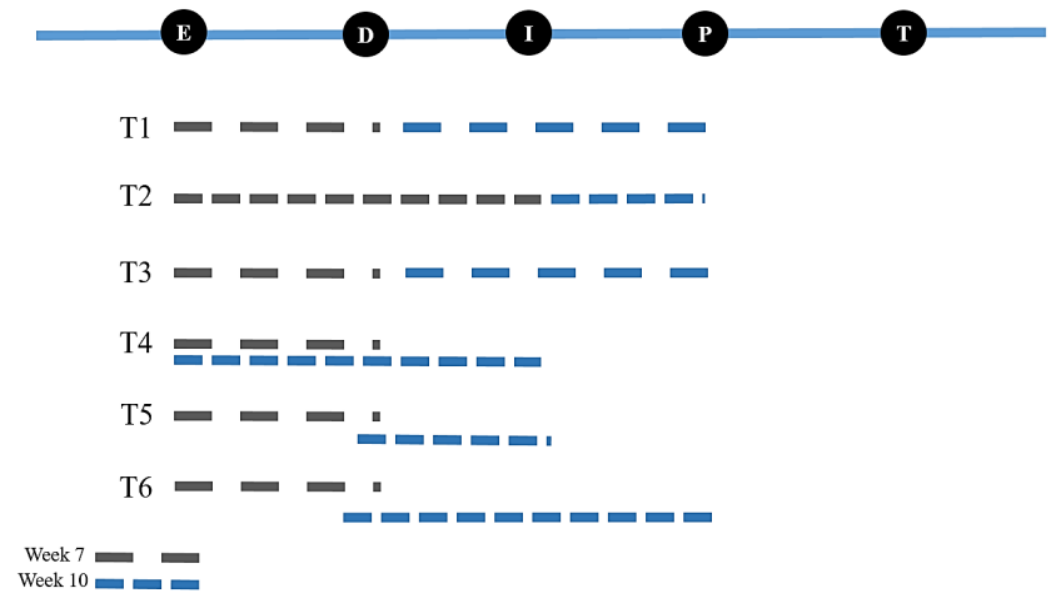

PICBE |

Figure 4. Stages in design-thinking and teams' evolution throughout the course

Author's own processing.

Comparing the two matrixes, we observe that:

(1) The more the venture develops, the more the teams divide into sets of three students and assign separate tasks for each set, performing tasks based on competence and in groups.

(2) Teams tend to use convergent thinking in the idea generation process as well as throughout whole the process, which is normal once they got closer to the prototyping phase. This pattern of convergent thinking might be influenced by the fact that these ventures were started in the previous year and a solution has been identified already.

As far as students' recommendations for designing the venture development process, these were divided into 4 categories (figure 5).

\begin{tabular}{|l|l|}
\hline $\begin{array}{l}\text { Communication } \\
\text { "Each team should be invited to share weekly } \\
\text { in class the progress made." }\end{array}$ & $\begin{array}{l}\text { Resources } \\
\text { "Better data collection in the trip in Kenya: } \\
\text { videos, documents." } \\
\text { Kenya." }\end{array}$ \\
\hline $\begin{array}{l}\text { Goals } \\
\text { "Be more specific on the expected goals for } \\
\text { each group." } \\
\text { "More consistency in the expectations." not necessary on paper." } \\
\text { "More achievable goals." }\end{array}$ & $\begin{array}{l}\text { Team design and teamwork conditions } \\
\text { "A smaller group size: maximum } 8 \text { people." } \\
\text { " A physical space dedicated to HESE to work }\end{array}$ \\
\hline $\begin{array}{l}\text { with the other teams; creates a community." } \\
\text { " More worktime in class for the venture } \\
\text { development". }\end{array}$
\end{tabular}

Figure 5. Participants' recommendations for a better venture development process

Author's own processing.

\section{Conclusions}

This research revealed that the students enrolled in the ENGR 451 social entrepreneurship for development of technology-based ventures, develop skills, attitudes and behaviors in nine areas: six of these areas are specific to the typical entrepreneurial mindset of an entrepreneur-oriented towards profit (opportunity recognition, comfort with risk, creativity and innovation, future orientation, critical thinking and problem solving, and communication and collaboration), and three categories specific to this course experience (focus on social impact, envisioning a social 
entrepreneurship career path, and mindful of culturally appropriate venturing). The nine areas together compose the HESE Humanitarian Entrepreneurial mindset.

Research about the culturally fit technology-based social ventures revealed that the more the venture develops, the more the team members divide the group into smaller units of three to four students, to perform separate tasks for the team. The team assigns tasks based on competence even if during the first stages of the venture development, in the empathizing and defining phases, they were assigning tasks based on preference. Moreover, teams tend to use convergent thinking in the idea generation process as well as throughout the process. In the last two weeks of the course, the ventures tend to be closer to the prototyping phase, achieving the goal of the course. However, few of them followed a non-linear design-thinking process by going back at least once to the empathizing and defining stages. To conclude, most teams manage to get the venture from an initial stage of problem reframing to a prototyping phase in a fourteen-week, design-thinking driven process.

As far as students' recommendations for designing the venture development process, these were related to communication, resources, goals, team design, and team-work conditions. The HESE team, professor and researchers implemented the recommendations in the following HESE sequence course, EDSGN 453 on developing communities.

\section{Limitations}

The results of this study reveal how the participants experience task-role assigning, design-thinking process, and idea generation and the skills, attitudes, and behaviors student acquire through this course experience. The conclusions must be considered within the context of the study where the sample size consisted of 49 undergraduate students where $70 \%$ are studying engineering. Therefore, this study was situated in an engineering context. Because most of the students who participated in the study were engineering students, the findings represent variation primarily of engineering students' experiences. However, this work lays a solid foundation for future studies that would include a larger number of students from other majors, in a context where interdisciplinary teams develop culturally fit technology-based social ventures.

\section{Acknowledgements}

This study was part of the research performed at Penn State University, The College of Engineering, USA with the support of Professor John Gershenson as part of the Fulbright Scholarship awarded by the Romanian-U.S. Fulbright Commission, Fulbright Program, The Government of the United States of America, and the Romanian Government.

\section{References}

Amabile, T. M. (1998). How to kill creativity, Harvard Business Review, 76(5), 76-87.

Borgaza, C., Defourny, J. (2001). The Emergence of Social Enterprise, London, Routledge.

Bornstein, D., and Davis, S. (2010). Social entrepreneurship: What everyone needs to know, New York, NY: Oxford University Press.

Braun, V., Clarke, V. (2006). Using thematic analysis in psychology, Qualitative research in psychology, 3(2), 77-101.

Brock, D. (2011). Social entrepreneurship education resource handbook, Ashoka U-Global Academy for Social Entrepreneurship. 
Charmaz, K. (2006). Constructing grounded theory: A practical guide through qualitative analysis, Thousand Oaks, CA, Sage.

Clough, C.G. (2005). Educating the Engineer of 2020: Adapting Engineering Education to the New Century, Washington, DC, National Academy of Engineering: National Academy Press.

Defourny, J., Nyssens, M. (2010). Conceptions of Social Enterprise and Social Entrepreneurship in Europe and the United States: Convergences and Divergences, Journal of Social Entrepreneurship, Vol. 1, 32-53, doi: 10.1080/19420670903442053.

Directorate-General for Employment (2015). Social Affairs and Inclusion, A map of social enterprises and their eco-systems in Europe, retrieved from: https://ec.europa.eu/social/ BlobServlet?docId=12987\&langId=en.

Douglas, H. (2015). Designing Social Entrepreneurship Education, International Journal of Social Entrepreneurship and Innovation, 3(5), 362-373.

European Commission (2014). A map of social enterprises and their eco-systems in Europe: Executive Summary, retrieved from: http://ec.europa.eu/social/BlobServlet?docId=12988 \&langId=en.

Glaser, B.G., Strauss, A.L. (1996). The discovery of grounded theory: Strategies for qualitative research, New York, NY, Aldine de Gruyter.

Glaser, B.G. (1999). The future of grounded theory, Qualitative Health Research, 9(6), https:// doi.org/10.1177/104973299129122199.

Gold, T., Rodriguez. S. (2018). Measuring Entrepreneurial Mindset in youth: learnings from NFTE's Entrepreneurial Mindset Index, retrieved from: http://www.nfte.com/wp-content/ uploads/2017/12/NFTE-Whitepaper-Measuring-Entrepreneurial-Mindset-in-Youth-Nove mber-2018.pdf.

Guilford, J. P. (1967). The nature of human intelligence, New York, NY: McGraw-Hill.

HESE website, 2018, retrieved from: http://sites.psu.edu/hese/.

Huang-Saad, A.Y., Morton, C.S., Libarkin, J.C. (2018). Entrepreneurship Assessment in Higher Education: A Research Review for Engineering Education Researchers, The Research Journal for Engineering Education, 107(2), 263-260, https://doi.org/10.1002/jee.20197.

Japan Research Institute (2016). Study of Social Entrepreneurship and Innovation Ecosystems in South East and East Asian Countries, retrieved from: https://publications.iadb.org/en/publi cation/study-social-entrepreneurship-and-innovation-ecosystems-south-east-and-eastasian-5.

Lindlof, T.L., Taylor, B.C. (2002). Qualitative Communication Research Methods, Sage Publications.

Mehta, K., Zappe, S., Brannon, M.L., Zhao, Y. (2016). An Educational and Entrepreneurial Ecosystem to Actualize Technology-Based Social Ventures, Advances in Engineering Education, 5(1), 1-38.

Morse, J.M. (1995). The significance of saturation, Qualitative Health Research, Vol. 5, 147-149, doi:10.1177/104973239500500201.

OECD/EU (2017). Boosting Social Enterprise Development: Good Practice Compendium, OECD Publishing, Paris, http://dx.doi.org/10.1787/9789264268500-en.

Osberg, S., Martin, R. (2015). Two Keys to Sustainable Social Enterprise, Harvard Business Review, retrieved from: https://hbr.org/2015/05/two-keys-to-sustainable-social-enterprise.

Patton, M.Q. (2002). Two Decades of Developments in Qualitative Inquiry: A Personal, Experiential Perspective, Qualitative Social Work, 1(3), https://doi.org/10.1177/147332 5002001003636. 
Parkinson, C. (2011). Enterprise in deprived areas: The crafting of an (un)-enterprising Community. Unpublished PhD Thesis, Lancaster University.

Rametse, Nthati, \& Shah, Hetal (2012). Investigating Social Entrepreneurship in Developing Countries, SSRN Electronic Journal, 10.2139/ssrn.2176557.

Retna, K. (2016). Thinking about "Design Thinking": A Study of Teacher Experiences, Asia Pacific Journal of Education, Vol. 36, suppl. 1, 5-19.

Runco, M.A. (2007). Creativity. Theories and themes: Research, development, and practice, Burlington, MA, Elsevier Academic Press.

Smith-Milway, K., Driscoll-Goulay, C. (2013). The Rise of Social Entrepreneur ship in B-Schools in Three Charts, retrieved from https://hbr.org/2013/02/the-rise-of-social-entrepreneur.

Strauss, A., Corbin, J. M. (1998). Basics of qualitative research techniques, Sage Publications.

Stempfle, J., Hübner, O., Badke-Schaub, P. (2001). A Functional Theory of Task Role Distribution in Work Groups, Group Processes \& Intergroup Relations, 4(2), 138-159, doi: 10.1177/ 1368430201004002005.

The Guardian (2013). Universities begin to unlock the potential of social enterprise, retrieved from: https://www.theguardian.com/social-enterprise-network/2013/jul/26/higher-educationsocial-enterprise-innovation.

The Guardian (2018). How social entrepreneurs are using tech-based solutions to tackle global poverty, retrieved from: https://www.theguardian.com/business-call-to-action-partnerzo ne/2018/sep/21/how-social-entrepreneurs-are-using-tech-based-solutions-to-tackle-globalpoverty.

The United Nations (2015). The 2030 Agenda for Sustainable Development, retrieved from https://sustainabledevelopment.un.org/post2015/transformingourworld.

The World Bank (2018). Poverty and Shared Prosperity Report, Piecing Together the Poverty Puzzle, retrieved from: http://www.worldbank.org/en/publication/poverty-and-sharedprosperity.

Thornberg, R. (2012). Informed grounded theory, Scandinavian Journal of Educational Research, Vol. 56, 243-259.

UNDP Regional Bureau for Europe and the Commonwealth of Independent States (2008). Social Enterprise: A new model for poverty reduction and employment generation, ISBN: 97892-9504-278-0, retrieved from: http://www.undp.org/content/undp/en/home/librarypage/ poverty-reduction/inclusive_development/social_enterpriseanewmodelforpovertyreductio nandemploymentgenera.html.

Zoltowski, C.B., Oakes, W.C., Cardella, M.E. (2012). Students' Ways of Experiencing HumanCentered Design, Journal of Engineering Education, Washington, 101(1), 28-59.

Weisberg, R.W. (1999). Creativity and knowledge: A challenge to theories, in R. J. Sternberg (Ed.), Handbook of Creativity, 226-250, Cambridge, UK, Cambridge University Press. 